\title{
Comparative study of some enzymes in different varieties of fruits
}

\author{
R. E. OKONJI ${ }^{1 *}$ and O. S. AGBOOLA ${ }^{2}$ \\ ${ }^{I}$ Department of Biochemistry, Obafemi Awolowo University, Ile-Ife, Nigeria. \\ ${ }^{2}$ Institute of Education, Obafemi Awolowo University, Ile-Ife, Nigeria. \\ *Corresponding author,Email: okonjire@yahoo.co.uk ; reokonji@oauife.edu.in
}

\begin{abstract}
Arginase, rhodanese and thiaminase are enzymes often encountered and that play crucial roles in different metabolic pathways. These enzymes were found to be present in different fruits: avocado pear (Persea americana), water melon (Citrullu slanatus), green exotic apple (Malus domestica), red exotic apple (Malus pumila), red local apple (Syzygium malaccense); pink local apple (Syzygium samarangense); sweet orange (Citrus sinensis), tangerine (Citrus tangerina), lime (Citrus aurantifolia), pawpaw (Carica papaya), banana (Musa acuminata), pineapple (Ananas comosus) and grape (Citrus paradisi). It was found that avocado pear has highest activity of arginase, rhodanese and thiaminase than the rest of the fruits investigated. The specific activity of rhodanese was however highest in water melon while that of arginase was more or less the same in red local apple and avocado pear. Arginase was also seen to vary significantly in the different plant samples with orange having the highest mean value of activity while sweet potato showed no activity. The study provides information on the presence of thiaminase, arginase and rhodanese in the different plants for nutritional purpose.
\end{abstract}

() 2014 International Formulae Group. All rights reserved.

Keywords: Enzymes, arginase, rhodanese, thiaminase, fruits.

\section{INTRODUCTION}

In the course of evolution, plants have elaborated protective mechanisms that allow them to successfully resist different kinds of unfavorable conditions including insects and phytopathogenic microorganisms (Freeman and Beattle, 2008; Ines and Marcos, 2013). The most important components of all protective mechanisms are proteinaceous compounds. These include enzymes such as $\beta$ 1,3-glucanases and chitinases, inhibitors of proteases and a-amylases, lectins, and also other proteins and peptides which have antimicrobial activity (Walski et al., 2005;
Candido et al., 2011). For instance, damaging of tomato leaves (Lycopersicon esculentum [Mill.]) by insects and microorganisms induced the synthesis of more than 20 different proteins including inhibitors of serine, cysteine, and aspartic proteinases and also a metallocarboxypeptidase (Stout et al., 2006; Howe and Jander, 2008).

Plants have also been found to be important for human life in many ways. Plants make up the largest proportion in human diet. Plants play an important role in maintaining balance in echo-system. Plant extracts contain many chemical compounds which are 
biologically active within the human body. For centuries, humans have used plants and plant extracts to treat various disease conditions and more recently to produce new drugs. Still, most of the plants carry a large number of unidentified compounds which can be useful in making new drugs.

Some of the best sources for enzymes are fresh fruits, vegetables, and sprouted grains. Just as the body needs enzymes to function, so do plants need enzymes for growth, reproduction, and health. Foods are such rich sources of enzymes that some enzyme supplements are actually derived from food sources. These include pineapple (the source of the enzyme bromelain), and papaya (the source of papain), as well as kiwi and figs. All fresh fruits, vegetables, or grains are potential enzyme sources, but only if the enzymes have not been destroyed by heat, radiation, or any of the other processes. Rhodanese has been confirmed to exist in plants and the enzyme has been proposed to have a role in cyanide detoxification (Hatzfeld and Saito, 2000; Saidu, 2005; Papenbrock et al., 2011). Arginase and thiaminase have also been reported in some plants. The presence of enzymes in fruits has been reported with little known information about their functions. Metabolic enzymes are important for the development and proper formation of cells and tissues in the body. The common fruits in Nigeria are seasonal and as such, the need to exploit the nutritional composition beyond the known proximate analysis that only expresses the protein and other crude contents. The secondary nutrient "enzymes" are not well known. This study therefore aimed at making available information on the presence of some important metabolic enzymes such as rhodanese, thiaminase and arginase in these fruits and to ascribe possible roles for the enzymes.

\section{MATERIALS AND METHODS Materials}

Trizma base, Trizma-HCl, thiamine, aniline and p - dimethylaminobenzaldelyde (Ehrlich reagent) were purchased from Sigma
Chemical Company, St. Louis, Mo, USA. Sodium chloride, orthophosphoric acid and manganese chloride tetrahydrate were purchased from BDH Chemicals Limited, Poole, England. All reagents used were of analytical grade and were either obtained from Sigma Chemical Company, St. Louis U.S.A or BDH Chemicals Limited, Poole, England. The fruits samples were purchased from a local market in Ile-Ife town, South-West, Nigeria.

\section{Methods \\ Preparation of crude extract}

The fruit samples were washed with saline water to remove dirty particles and were cut into small bits. $20 \mathrm{~g}$ of each fruit was homogenised in three volumes of $0.02 \mathrm{M}$ phosphate buffer, $\mathrm{pH}$ 7.2. This was followed by filtration using cheese cloth. The filtrate was then centrifuged at $4000 \mathrm{rpm}$ for 30 mins. The supernatant was collected and used for the analysis.

\section{Enzyme and protein essays}

Protein concentration was extrapolated from standard curve using bovine serum albumin (BSA) as standard according to the method described by Bradford (1976).

Arginase activity was determined according to the modified method of Kaysen and Strecker (1973). The reaction mixture contained in final concentration, $1.0 \mathrm{mM}$ Tris$\mathrm{HCl}$ buffer, pH 9.5 containing $1.0 \mathrm{mM} \mathrm{MnCl}_{2}$, $0.1 \mathrm{M}$ arginine and $50 \mu \mathrm{l}$ of the enzyme preparation was added in a final volume of 1.0 $\mathrm{ml}$. The mixture was incubated for 10 minutes at $37{ }^{\circ} \mathrm{C}$. The reaction was terminated by the addition of $2.5 \mathrm{ml}$ Erhlich reagent. The optical density reading was taken after 20 minutes at $450 \mathrm{~nm}$. The urea produced was estimated from the urea curved prepared by varying the concentration of urea between $0.1 \mu \mathrm{mol}$ and $1.0 \mu \mathrm{mol}$ and a graph of optical density against urea concentration was plotted. The unit of activity of arginase is defined as the amount of enzyme that will produce one $\mu \mathrm{mol}$ of urea per min at $37^{\circ} \mathrm{C}$.

Thiaminase assay carried out using modified method of Nishimune et al. (2000). 
The enzyme sample was incubated at $37{ }^{\circ} \mathrm{C}$ in $0.1 \mathrm{M}$ Tris-HCl buffer, $\mathrm{pH} 8.0$, with $10^{-5} \mathrm{M}$ thiamine and $4 \times 10^{-3} \mathrm{M}$ aniline and incubated for $30 \mathrm{~min}$. The remaining thiamine was oxidized with the addition of $1.0 \mathrm{ml}$ of $20 \%$ $\mathrm{NaOH}$ and assayed spectrophotometrically. Absorbance was read at $411 \mathrm{~nm}$. One unit of enzyme activity is that amount of enzyme which catalyses the formation of one micromole of heteropyrithiamine in $30 \mathrm{~min}$.

Rhodanese activity was assayed by the method of Agboola and Okonji (2004). The reaction mixture contained $50 \mathrm{mM}$ sodium thiosulphate, $50 \mathrm{mM}$ potassium cyanide, 0.25 $\mathrm{mM}$ borate buffer, $\mathrm{pH} 9.4$ and $10 \mu \mathrm{l}$ of enzyme solution in a final volume of $1.0 \mathrm{ml}$. The reaction was carried out for $1 \mathrm{~min}$ at $37^{\circ} \mathrm{C}$ and stopped by adding $0.5 \mathrm{ml} \quad 15 \%$ formaldehyde and $1.5 \mathrm{ml}$ of Sorbo reagent (which is made up of ferric nitrate solution containing $0.025 \mathrm{~g} \mathrm{Fe}(\mathrm{NO} 3)_{3}$ in $0.74 \mathrm{ml}$ water and $0.26 \mathrm{ml}$ concentrated nitric acid). Absorbance was measured at $460 \mathrm{~nm}$. The unit of enzyme activity was defined as micromoles thiocyanate formed per minute at $37^{\circ} \mathrm{C}$ and $\mathrm{pH} 9.2$.

\section{Statistical analysis}

The results are presented as means \pm SD. Data were analyzed by one-way ANOVA by using SAS/PC software to examine whether there was any statistical difference among groups. If the difference evaluated with the ANOVA was significant, Duncan multiple range test was used for paired comparisons. A $P$ value less than 0.05 was considered statistically significant.

\section{RESULTS}

The activities of three different enzymes (arginase, rhodanese and thiaminase) in fruits were determined. The results presented in Tables 1 and 2 show the protein concentration and specific activities of the three enzymes respectively in the fruits studied. Avocado pear showed the highest mean value of protein and pineapple contained the least amount of protein (Table 1).

In this study, highest specific activity of thiaminase was found in grape $(1.381 \pm 0.90)$ followed by pawpaw and sweet orange with specific activities of $0.445 \pm 0.26$ and $0.128 \pm 0.01$ respectively. Banana and pineapple showed no activity of the thiaminase enzyme. The highest specific activity of arginase was found in sweet orange with a value of $80.120 \pm 19.88$. This was followed by lime and grape with specific activities of $13.090 \pm 3.42$ and $10.500 \pm 0.00$ respectively. Banana showed no activity of the enzyme (Table 2). For rhodanese, the highest specific activity was found in pawpaw with a value of $6.240 \pm 3.82$, while tangerine contained no rhodanese.

\section{DISCUSSION}

Fruits are not generally known for their protein content, since most have very modest levels compared with the usual high protein foods like fish, eggs and soy. However, certain fruits have far more protein than others. In animals, rhodanese has been found to be present in high concentration in the liver followed by the kidney (Ali et al., 2001; Aminlari et al., 2002; Agboola and Okonji, 2004; Abdeirahman and Khogali, 2010). Its distribution in different tissues in animals has been described extensively (Ali et al., 2001; Aminlari et al., 2002; Cipollone et al., 2008) Different roles have been proposed for this enzyme in the different tissues where it is located. For example, electron transport system in the mitochondrion depends on the availability of rhodanese for it functions since the system is susceptible to cyanide attack (Nandi et al., 2000; Ali et al., 2001). Some other authors have reported that rhodanese activity in plants is due to the action of other enzyme(s). 
Table 1: Protein concentrations of the fruits.

\begin{tabular}{|c|c|}
\hline Fruit samples & Protein concentration (mg) \\
\hline Green exotic apple (Malus domestica) & $421.34 \pm 48.80$ \\
\hline Red exotic apple (Malus pumila) & $521.14 \pm 2.33$ \\
\hline Red local apple (Syzygium malaccense) & $827.64 \pm 0.00$ \\
\hline Pink local apple (Syzygium samarangense) & $489.98 \pm 20.90$ \\
\hline Water melon (Citrullu slanatus) & $586.66 \pm 2.27$ \\
\hline Avocado pear (Persea americana) & $1967.22 \pm 0.00$ \\
\hline Tangerine $\quad$ (Citrus tangerina) & $195.22 \pm 48.80$ \\
\hline Grape $\quad$ (Citrus paradisi) & $52.8 \pm 0.00$ \\
\hline (Carica papaya) & $54.4 \pm 20.90$ \\
\hline (Musa acuminata) & $5.36 \pm 2.27$ \\
\hline Pineapple $\quad$ (Ananas comosus) & $2.63 \pm 0.11$ \\
\hline Sweet orange (Citrus sinensis) & $77.8 \pm 9.29$ \\
\hline (Citrus aurantifolia) & $434.9 \pm 167.10$ \\
\hline$p$ - value & $<6.23$ \\
\hline
\end{tabular}

Table 2: The specific activities of the enzymes.

\begin{tabular}{lccc}
\hline Fruit samples & $\begin{array}{c}\text { Thiaminase SA } \\
(\mathbf{U} / \mathbf{m g})\end{array}$ & $\begin{array}{c}\text { Arginase SA } \\
(\mathbf{U} / \mathbf{m g})\end{array}$ & $\begin{array}{c}\text { Rhodanese SA } \\
(\mathbf{U} / \mathbf{m g})\end{array}$ \\
\hline Green exotic apple (Malus domestica) & $0.011 \pm 0.01$ & $0.240 \pm 0.01$ & $0.0554 \pm 0.00$ \\
Red exotic apple (Malus pumila) & $0.087 \pm 0.01$ & $0.348 \pm 0.19$ & $0.208 \pm 0.85$ \\
Red local apple (Syzygium malaccense) & $0.001 \pm 0.00$ & $1.053 \pm 0.00$ & $0.092 \pm 0.00$ \\
Pink local apple (Syzygium samarangense) & $0.026 \pm 0.01$ & $0.982 \pm 0.01$ & $0.159 \pm 3.82$ \\
Water melon (Citrullu slanatus) & $0.001 \pm 0.00$ & $0.235 \pm 0.00$ & $2.105 \pm 0.44$ \\
Avocado pear (Persea americana) & $0.007 \pm 0.00$ & $1.071 \pm 0.16$ & $0.8771 \pm 0.07$ \\
Tangerine (Citrus tangerina) & $0.036 \pm 0.01$ & $3.780 \pm 0.87$ & $0.000 \pm 0.00$ \\
Grape (Citrus paradisi) & $1.381 \pm 0.90$ & $10.500 \pm 0.00$ & $4.090 \pm 0.90$ \\
Pawpaw (Carica papaya) & $0.445 \pm 0.26$ & $6.300 \pm 2.71$ & $6.240 \pm 3.82$ \\
Banana (Musa acuminata) & $0.0000 \pm 0.00$ & $0.000 \pm 0.00$ & $0.440 \pm 0.44$ \\
Pineapple (Ananas comosus) & $0.0000 \pm 0.00$ & $0.440 \pm 0.16$ & $0.130 \pm 0.07$ \\
Sweet orange (Citrus sinensis) & $0.128 \pm 0.01$ & $80.120 \pm 19.88$ & $4.210 \pm 3.48$ \\
Lime (Citrus aurantifolia) & $0.086 \pm 0.05$ & $13.090 \pm 3.42$ & $3.650 \pm 1.12$ \\
\hline \multicolumn{1}{c}{$\boldsymbol{p}$ - value } & $<\mathbf{2 . 0 7}$ & $<\mathbf{1 0 . 2 3}$ & $<\mathbf{0 . 8 5}$ \\
\hline \multicolumn{1}{c}{ Data are triplicate determinations, SA= Specific activity } & &
\end{tabular}

It has been suggested that the level of rhodanese in different tissues of animals is correlated with the level of exposure to cyanide (Aminlari et al., 2002). The primary physiological function of this enzyme was originally believed to be a direct role in the conversion of inorganic cyanide to the less toxic thiocyanate anion (Cipollone et al., 2008; Papenbrock et al., 2011). The wide spread distribution and abundance of rhodanese as well as its subcellular localization in the matrix of liver and kidney mitochondria suggest additional functions. It is now recognized that rhodanese is part of a system that provides sulfane sulfur for use in the formation of the characteristic prosthetic group of iron-sulfur proteins (Bordo and Bork, 2002; Cipollone et al., 2008). There is 
also evidence indicating that, by virtue of this role, rhodanese may be involved directly in the modulation of mitochondrial respiratory activity (Papenbrock et al., 2011). In this study, the distribution of rhodanese in the different fruits may suggest other functions other than cyanide detoxification, for example, such function as modulation of energy production as suggested by Aussignargues et al. (2012). It is believed that the primary function of rhodanese is cyanide detoxification but its wide distribution in different tissues suggests that there may be other functions, including formation of iron sulphur centre in proteins, participation in energy metabolism, a thioredoxin oxidase and detoxification of hydrogen sulphide (Shahbazkia et al, 2009). Along with inhibitors of trypsin and chymotrypsin, many plants also have proteins that act predominantly as inhibitors of microbial proteinases (Huma and Majid, 2007; Sabotic and Kos, 2012).

Arginase, a primordial enzyme, is found throughout the primary kingdoms of life (McGee et al., 2004; Dabir et al., 2005; Mohamed et al., 2005). It plays a critical role in the hepatic metabolism of most of the higher organisms as a cardinal component of the urea cycle. Additionally, it occurs in numerous organisms and tissues where there is no functioning urea cycle. Extra-hepatic arginase may supply cells with ornithine that is converted to proline and glutamate. The comparison of arginase activity in the selected fruits reveals that pink local apple, red local apple and avocado pear have considerably high specific activity when compared to water melon, green exotic apple and red exotic apple. Most of the studies on plant arginase have focused on its role in mobilizing arginine during early seedling germination. Storage proteins are mobilized to provide amino acids for protein synthesis in the expanding axis. Arginase activity increases sharply during germination in several species including shade plant, ginseng (Hwang et al., 2001), arabidopsis and loblolly pines (Todd et al, 2001). In higher plants, urea and ornithine formed as products of arginase reaction are used in the assimilation of nitrogen into amino acids and the synthesis of polyamines through urease and ornithine decarboxylase respectively (Chen et al., 2004; Dabir et al., 2005; Zhang et al., 2010).

Thiaminase is found in several species of bacteria and other higher organisms (Nishimune et al., 2000; Wistbacka et al., 2009). Thiaminase was once causing economical losses in raising fisheries, e.g. in yellowtail fed raw anchovy as a sole feed for a certain period, and also in sea bream and rainbow trout. Thiaminase specific activity obtained from this study shows that thiaminase is low in the selected fruits (Table 2). Most of the fruits studied contained little or no thiaminase activity when compared to the other enzymes. In Nigeria, there have been reports of outbreak of disease after consumption of larvae of Anaphe venata which serves as a supplemental protein nutrition (Bamitale et al., 2011). Similar case was reported in Côte d'Ivoire (Ahoua et al., 2007). Animals that consume thiaminasecontaining foods can experience thiamin deficiency-related illnesses (Nishimune et al., 2000; Honeyfield et al., 2010).

\section{Conclusion}

This study showed a wide spread distribution of rhodanese, arginase and thiaminase enzymes in the fruit samples. The presence of these enzymes in the fruits especially rhodanese and arginase suggest these enzymes may be functional in many physiological activities.

\section{REFERENCES}

Abdelrahman SH, Khogali SME. 2010. Cyanide-Metabolizing Enzymes in Camels (Camelus dromdarius). Vet. Res., 3(2): 29-31.

Agboola FK, Okonji RE. 2004. Presence of rhodanese in the cytosolic fraction of the fruit bat (Eidolon helvum) liver. J. Biochem. Mol. Biol., 37(33): 275-281.

Ahoua L, Etienne W, Fermon F, Godain G, Brown V, Kadjo K. 2007. Outbreak of 
beriberi in a prison in Côte d'Ivoire. Food Nutr. Bull., 28(3): 283-290.

Ali A, AL-Qarawi A, Hassan M, Mousa BH. 2001. Tissue and intracellular distribution of Rhodanese and mercaptoethanol sulphurtransferase in ruminants and birds. Vet. Res., 32: 6370 .

Aminlari M, Tjalve H, Larsson P. 2002. Distribution of the cyanide metabolizing enzyme-rhodanese in different tissues of domestic animals. J. Vet. Pharmacol., 26(11): 109-128.

Aussignargues C, Giuliani M, Infossi P, Lojou E, Guiral M, Giudici-Orticoni M, Ilbert M. 2012. Rhodanese functions as sulfur supplier for key enzymes in sulfur energy metabolism. J. Biol. Chem., 287: 19936-19948.

Bamitale KDS, Akanmu MA, Okonji RE, Obuotor EM, Ukponmwan OE. 2011. Involvement of cholinergic-muscarinic receptor in Anaphe venata-induced stretching-ataxia behavioral effects in rats. Int. J. Biol. Chem. Sci., 5(3): 851860.

Bradford KM. 1976. A rapid and sensitive method for the quantitation of micrograme quantities of protein utilizing the principle of protein-dye binding. Anals Biochem., 72: 248-254.

Bordo D, Bork P. 2000. The rhodanese/Cdc25 phosphatase superfamily.Sequencestructure-function relations. EMBO Reports., 3(8): 741-746.

Cândido ES, Pinto MF, Pelegrini PB, Lima TB, Silva ON, Pogue R, Grossi-de-Sá MF, Franco OL. 2011. Plant storage proteins with antimicrobial activity: novel insights into plant defense mechanisms. FASEB J., 25(10): 3290305.

Chen H, McCaig BC, Melotto M, He SY, Howe GA. 2004. Regulation of plant arginase by wounding, jasmonate, and the phytotoxin coronatine Source. J. Biol Chem., 29(44): 45998-46007.

Cipollone R, Ascenzi P, Tomao P, Imperi F, Visca P. 2008. Enzymatic detoxification of cyanide: clues from Pseudomonas aeruginosa rhodanese. J. Mol. Microbiol. Biotechnol., 15(2-3): 199211.

Dabir S, Dabir P, Somvanshi B. 2005. Purification, properties and alternate substrate specificities of arginase from two different sources: Vigna catjang cotyledon and buffalo liver. Int. J. Biol. Sci., 1: 114-122.

Freeman BC, Beattie GA. 2008. an overview of plant defenses against pathogens and herbivores. The Plant Health Instruc., DOI: 10.1094/PHI-I-2008-0226-01.

Hatzfeld Y, Saito K. 2000. Evidence for the existence of rhodanese (thiosulfate: cyanide sulfurtransferase) in plants: preliminary characterization of two rhodanese cDNAs from Arabidopsis thaliana. FEBS Lett., 470(2): 147-150.

Honeyfield DC, Hanes JW, Brown L, Kraft CE, Begley TP. 2010. Comparison of thiaminase activity in fish using the radiometric and 4-nitrothiophenol colorimetric methods. J. Great Lakes Res., 36(4): 641-645.

Howe GA, Jander G. 2008. Plant immunity to insect herbivores. Annu. Rev. Plant Biol., 59: 41-66.

Huma H, Majid F. 2007. Plant protease inhibitors: a defense strategy in plants. Biotech. Mol. Biol. Rev., 2(3): 068-085.

Hwang HJ, Kim EH, Cho YD. 2001. Isolation and properties of arginase from a shade plant, ginseng (Panax ginseng) roots. Phytochem., 58(7): 1015-1024.

Ines PL, Marcos M. 2013. Activation of defense mechanism against pathogens in mosses and flowering plants. Int. J. Mol. Sci., 14: 3178-3200.

Kaysen GA, Strecker HJ. 1973. Purification and Properties of Arginase of Rat Kidney. Biochem. J., 133: 779-788.

McGee DJ, Zabaleta J, Viator RJ, Testeman TL, Ochoa AC, Mendz GL. 2004. Purification and characterization of Helicobacter pylori arginase, RocF: unique features among the arginase 
superfamily. Eur. J. Biochem., 271: 1952- 1962.

Mohamed SA, Fahmy AS, Mohamed TM, Hamdy SM. 2005. Urea cycle of Fasciola gigantica: Purification and characterization of arginase. Comp. Biochem. Physiol., 142: 308-316.

Nandi DL, Horowitz PM, Westley J. 2000. Rhodanese as a thioredoxin oxidase. Int. J. Biochem. Cell Biol., 32(4): 465-473.

Nishimune T, Watanabe Y, Okazaki H, Akai H. 2000. Thiamin is decomposed due to Anaphe spp. entomophagy in seasonal ataxia patients in Nigeria. J. Nutr., 130: $1625-1628$.

Papenbrock J, Guretzki S, Henne M. 2011. Latest news about the sulfurtransferase protein family of higher plants. Amino Acids., 41(1):43-57.

Sabotič J, Kos J. 2012. Microbial and fungal protease inhibitors--current and potential applications. Appl. Microbiol. Biotechnol., 93(4):1351-1375.

Saidu Y. 2005. Physicochemical features of rhodanese: A review. Afri. J. Biotech., 3(4): 370- 374.

Shahbazkia HR, Aminlari M, Tavana M. 2009. Distribution of the enzyme rhodanese in tissues of the cat (Felis catus). J. Fel. Med. Surg., 11: 305-308.
Stout MJ, Thaler JS, Thomma B. 2006. Plantmediated interactions between pathogenic microorganisms and herbivorous arthropods. Annu. Rev. Entomol., 51: 663-689.

Todd DC, Cooke JEK, David JG. 2001. Purification and properties of Pinus taeda arginase from germinated seedlings. Plant Phys. Biochem., 39(12): 1037-1045.

Walski EA, Lima C, Agusti R, Daleo GR, Andrea AB, De ledekremer RM. 2005. An $\alpha$-glucan elicit from the cell wall of a biocontrol binucleate Rhizoctonia isolate. Carbohydr. Res., 340: 619-627.

Wistbacka S, Lonnstrom L, Bonsdorff E, Bylund G. 2009. Thiaminase activity of crucian carp Carassius carassius injected with a bacterial fish pathogen, Aeromonas salmonicida subsp. Salmonicida. J. Aquatic Ani. Health., 21: 217-228.

Zhang X, Shen L, Li F, Zhang Y, Meng D, Sheng J. 2010. Up regulating arginase contributes to amelioration of chilling stress and the antioxidant system in cherry tomato fruits. J. Sci. Food Agri., 90(13): 2195-2202. 